\title{
HYGIENIC ASSESSMENT OF THE CHEMICAL WEAPONS DESTRUCTION FACILITIES IN THE CONTEXT OF RELIEVING THE CONSEQUENCES OF THEIR OPERATION AND SUBSEQUENT CONVERSION THEREOF
}

Gulyaev DV $\otimes$

Research Institute of Hygiene, Occupational Pathology and Human Ecology FMBA, Leningrad region, Russia

\begin{abstract}
After elimination of the chemical weapons, it is necessary to relieve the consequences of operation of the chemical weapons destruction facilities (CWDF). This study aimed to assess the results of such relieve activities from the hygienic point of view. The assessment allows considering partial conversion of the CWDFs' infrastructure for civil purposes. At four CWDFs, the sites of contamination of equipment and infrastructural components with degradition products of organophosphorous agents (OPA) and blister agents (BA) were identified. The technologies that enabled analysis of the samples taken were high performance liquid chromatography with tandem mass spectrometry, gas chromatography-mass spectrometry, gas chromatography-tandem mass spectrometry, and atomic absorption spectroscopy with electrothermal atomization. The analysis revealed contamination of building structures, equipment, utility lines, waterproofing, heatinsulating, and other materials inside the CWDF process buildings, regardless of their purpose, with OPA and BA degradation products. In the absence of hygienic standards and information on their toxicity, it was impossible to assess the hazard thereof. In all the samples taken, the residual content of toxic substances was below the limit of detection of the measurement methods applied, i.e., none was found. The article presents a methodology for a stepwise hygienic assessment of the CWDF infrastructure to be converted and develops recommendations for its subsequent safe use. The conclusions state expediency of development of hygienic standards for the OPA and BA degradation products and development and certification of the relevant measurement procedures.
\end{abstract}

Keywords: chemical weapons, elimination, toxic substances, degradation products, hygiene standards, conversion

Author contribution: Gulyaev DV — study design, information collection, processing and analysis of the results, editing.

$\triangle$ Correspondence should be addressed: Dmitry V. Gulyaev

Kapitolovo, str. 93, r.p. Kuzmolovsky, Vsevolozhsky r., 188663, Leningradskaya obl.; gylya.spb@mail.ru

Received: 28.05.2021 Accepted: 13.06.2021 Published online: 25.06.2021

DOI: $10.47183 /$ mes.2021.016

\section{ГИГИЕНИЧЕСКАЯ ОЦЕНКА ОБЪЕКТОВ ПО УНИЧТОЖЕНИЮ ХИМИЧЕСКОГО ОРУЖИЯ ПРИ ЛИКВИДАЦИИ ПОСЛЕДСТВИЙ ДЕЯТЕЛЬНОСТИ И ПЕРЕПРОФИЛИРОВАНИИ}

\section{Д. В. Гуляев $\square$}

Научно-исследовательский институт гигиены, профпатологии и экологии человека Федерального медико-биологического агентства, Ленинградская область, Россия

\begin{abstract}
После уничтожения химического оружия необходимо проводить работы по ликвидации последствий деятельности объектов по уничтожению химического оружия (ОУХО). Целью работы было провести гигиеническую оценку результатов ликвидационных мероприятий для возможности вовлечения части производственной инфраструктуры ОУХО в хозяйственный оборот. На четырех ОУХО выявляли места загрязнения оборудования и элементов производственной инфраструктуры продуктами деструкции фосфорорганических отравляющих веществ (ФОВ) и отравляющих веществ кожно-нарывного действия (ОВ КНД). Пробы анализировали методами высокоэффективной жидкостной хроматографии с тандемным массселективным детектированием, газовой хроматомасс-спектрометрией, газовой хроматографии с тандемным масс-селективным детектированием и атомно-абсорбционной спектроскопии с электротермической атомизацией. Выявлено загрязнение строительных конструкций, оборудования, коммуникаций, гидроизоляционных, теплоизоляционных и других материалов, находящихся внутри производственных зданий ОУхО, вне зависимости от их предназначения, продуктами деструкции ФОВ и ОВ КНД, оценить степень опасности которых в отсутствие гигиенических нормативов и информации о токсичности не представлялось возможным. Во всех отобранных пробах остаточное содержание отравляющих веществ находилось ниже предела обнаружения методик выполнения измерений (не обнаружено). Представлена методика поэтапного гигиенического обследования необходимой к передаче инфраструктуры ОУХО с разработкой рекомендаций для последующего безопасного использования. Сделан вывод о целесообразности обоснования гигиенических нормативов продуктов деструкции ФОВ и ОВ КНД, разработки и аттестации методик выполнения измерений.
\end{abstract}

Ключевые слова: химическое оружие, ликвидация, отравляющие вещества, продукты деструкции, гигиенический норматив, перепрофилирование Вклад авторов: Д. В. Гуляев - дизайн исследования, сбор информации, обработка и анализ результатов; редактирование.

$凶$ Для корреспонденции: Дмитрий Владимирович Гуляев

г.п. Кузьмоловский, корп. 93, 188663, Всеволожский район, Ленинградская область; gylya.spb@mail.ru

Статья получена: 28.05.2021 Статья принята к печати: 13.06.2021 Опубликована онлайн: 25.06.2021

DOI: $10.47183 /$ mes.2021.016

In 1992, the Russian Federation (RF) signed the Chemical Weapons Convention (CWA) and undertook obligations to destroy chemical weapons stockpiles [1]. The country passed legislation to ensure implementation of the obligations under this international treaty $[2,3]$.

The RF had storage facilities for chemical ammunition filled with organophosphorous agents (OPA), such as $\mathrm{Vx}$, sarin, soman, and blister agents (BA), such as sulfur mustard, lewisite, and their mixtures. The chemical weapons stockpiles were destroyed at seven new chemical weapons destruction facilities (CWDF) built and commissioned at various times. The job of designing and constructing these facilities entailed development of solutions ensuring safety of operation of the CWDFs and deployment of the monitoring system that meets high requirements. There were developed regulatory and methodological documents governing organization of sanitary and epidemiological supervision and control, protection of industrial space and the environment, and health of the personnel and population.

The last piece of chemical munitions was destroyed in September 2017. Thus, the process of destroying RF's chemical weapons stockpiles was completed.

One of the problems to be solved under the Federal Target Program for the Destruction of Chemical Weapons Stockpiles 
Table 1. Number of samples taken at a CWDF

\begin{tabular}{|c|c|c|c|}
\hline CWDF & Total samples taken & Wipe samples & Solid samples of fragments of building structures and engineering infrastructure \\
\hline 1 & 218 & 62 & 156 \\
\hline 2 & 238 & 62 & 176 \\
\hline 3 & 219 & 98 & 121 \\
\hline 4 & 321 & 161 & 160 \\
\hline Total & 996 & 383 & 613 \\
\hline
\end{tabular}

in the Russian Federation [2] is relieving the consequences of operation of the chemical weapons storage and destruction facilities.

As CWDFs see the chemical weapons destruction process to completion, measures are taken to neutralize the facilities and make them safe and ready for subsequent conversion, including degassing of internal and external surfaces, dismantling equipment and building structures and cutting them into measured pieces, degassing of fragments, thermal neutralization, and waste landfilling.

Potentially, not just the destroyed chemical agents (CA) but also their toxic degradation products may contaminate building structures, equipment, utility infrastructure, waterproofing, heat-insulating, and other materials inside the buildings of facilities, which is a hazard.

The monitoring system designed to enable protection of people and the environment from the CA stays online and works during the CWDF operation consequences relieve process.

Conversion of a CWDF generates the risk of contamination of the process space and the environment with toxic substances adsorbed by the building structures and equipment.

Currently, there are active hygienic safety regulations for CAs that specify the maximum permissible concentration, MPC; maximum permissible level, MPL; tentatively safe exposure level, TSEL; approximate permissible concentration, TPC. There were also developed the methods ofmeasurement of the CA concentrations in the process space and the environment, at the site, on the skin and personal protective equipment, and in the wastes.

There were developed design documents describing the process of relieving the consequences of operation of CWDFs. These documents were reviewed and approved by the sanitary and epidemiological examination board. However, in order to preserve public funds and in the interests of industries supporting the state's defense capabilities and security (including production of gunpowders and explosives, active pharmaceutical ingredients and medicines, and waste disposal facilities treating hazard class I and II wastes), it was decided to partially preserve the process equipment and the engineering infrastructure elements signed for elimination, with the aim to convert them.

This study aimed to assess the results of such relieve activities from the hygienic point of view. The assessment allows considering partial conversion of the CWDFs' infrastructure for civil purposes, development and testing of the methodology of a phased hygienic examination necessary for the CWDF infrastructure conversion. It also enables recommendations for subsequent safe use.

\section{METHODS}

The first stage implied wipe sampling the surfaces of process equipment and elements of industrial infrastructure, collection of solid samples of fragments of building structures and elements of industrial infrastructure (floors, walls, inlet ventilation systems, power supply, lighting, heating, fire extinguishing systems) in order to identify the areas contaminated the most with the OPA and BA degradation products (Table 1; Figure).

The technologies that enabled analysis of the residual content of the OPA and BA degradation products were high performance liquid chromatography with tandem mass spectrometry (HPLC-MS/MS), gas chromatography-mass spectrometry (GC-MS), gas chromatography- tandem mass spectrometry (GC-MS/MS), and atomic absorption spectroscopy with electrothermal atomization (AAS-ETA) [4, 5].

Second stage implied wipe sampling surfaces of process equipment and elements of engineering infrastructure in order to measure the residual concentrations of OPAs and BAs by enzymatic methods and gas chromatography.

The data obtained were processed with STATISTICA 13.3 (StatSoft Inc.; USA).

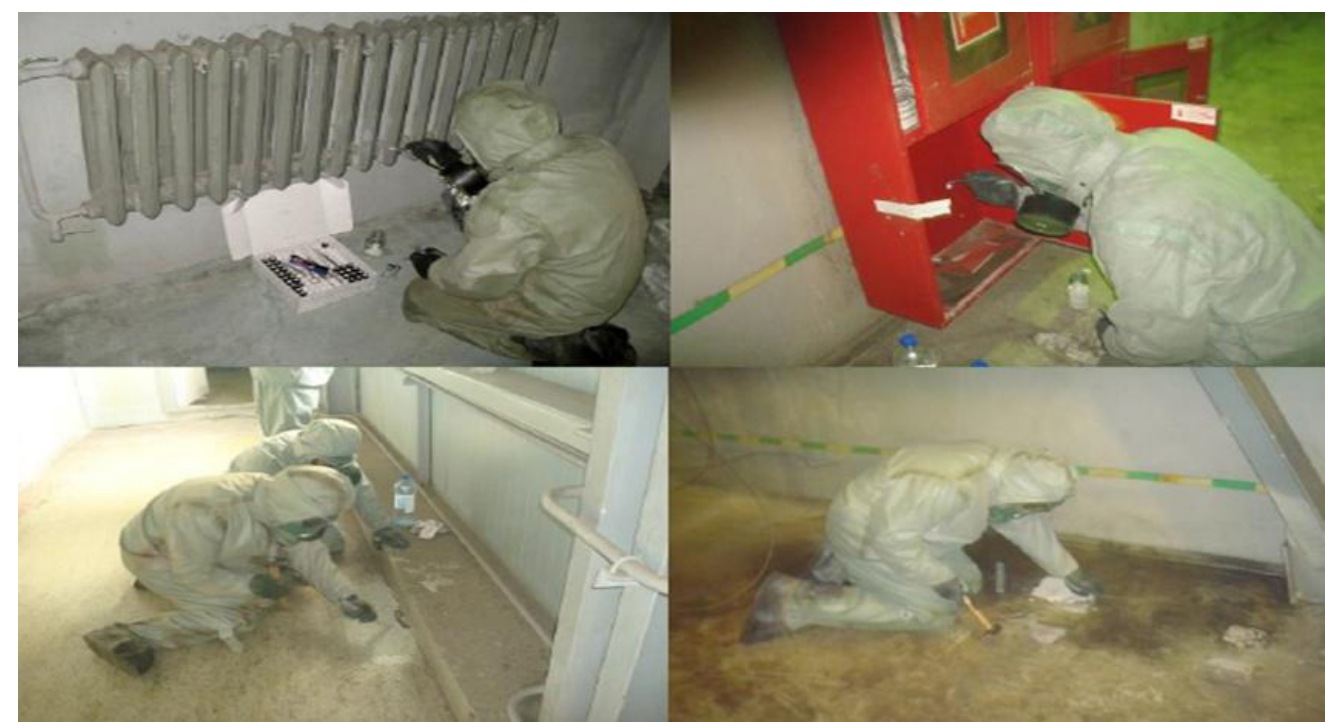

Fig. Sampling at the chemical weapons destruction facilities 
Table 2. Number of control samples taken at a CWDF

\begin{tabular}{|c|c|c|c|c|c|}
\hline \multirow{2}{*}{ CWDF } & \multicolumn{5}{|c|}{ CA identified } \\
\cline { 2 - 6 } & Vx type substance & sarin & soman & sulfur mustard & lewisite \\
\hline 1 & 118 & 107 & 118 & 39 & 39 \\
\hline 2 & 113 & 95 & 139 & - & - \\
\hline 3 & 265 & 161 & 265 & - & - \\
\hline 4 & 427 & 316 & 454 & - & - \\
\hline
\end{tabular}

\section{RESULTS}

The study yielded identification of the places (parts of equipment, engineering infrastructure) most contaminated with the OPA and BA degradation products at four CWDFs.

All the premises examined were contaminated with organic compounds typical for OPA destruction facilities: S-2(diethylaminoethyl) methylphosphonothioate, methylphosphonic acid (MPA), isopropyl-, isobutyl-, and pinacolylmethylphosphonic acid (MPA), diisobutyl, dipinacolyl, and isobutyl pinacolyl esters of MPA, and 2,2'-bis(diethylaminoethyl) disulfide.

In addition, most samples taken at facility \#1, rooms where BAs were destroyed, contained degradation products thereof: thiodiglycol, thiodiglycol oxide, and chlorovinylarsonic acid. A number of samples contained sulfur mustard. Arsenic was found in all the samples studied, with some showing values exceeding MPC and MPL.

It was not possible to assess the degree of hazard the detected chemical compounds present, since there are no relevant hygienic standards and information on toxicity.

Table 2 shows the results of analysis of control wipes taken from the surfaces (process equipment, engineering infrastructure) identified as the most contaminated with OPA and BA degradation products. The analysis aimed to determine the residual content thereof.

In all the samples taken, the residual content of OPA ( $V x$ type substance, sarin, soman) and BA (sulfur mustard, lewisite, mixtures thereof) was below the limit of detection of the measurement methods applied, i.e., none was found.

\section{DISCUSSION}

At four CWDFs, process equipment and engineering infrastructure were found to be contaminated with the OPA and BA degradation products, which indicates that the facilities were previously contaminated with the CA or with the reaction masses generated by their processing. Most likely, the compounds found in surface wipes and solid samples taken from the building structures and engineering infrastructure (wiring, cable conduits, lamps) originated from the source CA that degraded under degassing and the influence of various environmental factors (humidity, temperature etc) [4].

The study allowed compiling degassing recommendations that incorporate measures to assess the quality thereof (the degree of removal of OPA, BA, and their degradation products) after the relief operations. If it is impossible to meet the requirements of hygienic standards, it is necessary to carry out work in full in accordance with the project documentation.

To enable subsequent safe use of a CWDF, it is recommended to monitor the dynamics of the levels of OPA and BA degradation products for three years.

Development of the hygienic standards and methods to measure the CA degradation product levels (in facilities and the environment, the surface of personal protective equipment and wastes) is an important step supporting implementation of the recommendations after completion of the relief efforts at CWDFs enabling their subsequent use.

\section{CONCLUSIONS}

The analysis revealed contamination of building structures, equipment, utility lines, waterproofing, heat-insulating and other materials inside the CWDF buildings, regardless of their purpose, with products of degradation of OPA and BA. No OPA and BA were found in the wipes taken from the surfaces of process equipment and elements of the engineering infrastructure of the CWDFs. It is advisable to develop hygienic standards for OPA and BA degradation products (TSEL/ MPC in the process area air, APL/MPC on the surfaces of process equipment and PPE, APC/MPC in building structure rejects) and develop and certify the applicable measurement procedures.

\section{References}

1. Konvencija o zapreshhenii razrabotki, proizvodstva, nakoplenija i primenenija himicheskogo oruzhija i o ego unichtozhenii. Mezhdunarodnaja konferencija po podpisaniju Konvencii. GE.9261926. Parizh, 1993; 133 s. Russian.

2. Postanovlenie Pravitelstva Rossijskoj Federacii ot 21 marta 1996 g. \# 305 «Ob utverzhdenii federal'noj celevoj programmy «Unichtozhenie zapasov himicheskogo oruzhija v Rossijskoj Federacii». Sobranie zakonodatel'stva Rossijskoj Federacii. 1996; 14: 1448. Russian.

3. Federalnyj zakon ot 2 maja 1997 g. \# 76-FZ «Ob unichtozhenii himicheskogo oruzhija». Sobranie zakonodatel'stva Rossijskoj Federacii. 2006; 52: 5498. Russian.

4. Gulyaev DV, Kombarova MYu, Radilov AS, Rembovskij VR,

Saveleva El, Koryagina NL, i dr. Obespechenie sanitarnojepidemiologicheskoj bezopasnosti infrastruktury ob"ekta po unichtozheniju himicheskogo oruzhija «Pochep», planiruemogo k vovlecheniju $v$ hozjajstvennyj oborot. Medicina jekstremal'nyh situacii. 2019; 21 (4): 556-62. Russian.

5. Shmurak VI, Kessenih ED, Shachneva MD, Gustyleva LK, Aljushina TI, Korjagina NL, i dr. Opredelenie produktov destrukcii fosfororganicheskih soedinenij metodom VJeZhH-MS/MS. V sbornike: AS Radilov, VR Rembovskij, redaktory. Medikobiologicheskie aspekty himicheskoj bezopasnosti: sbornik trudov III Vserossijskoj nauchnoj konferencii molodyh uchenyh. SPb., 2018; s. 51-52. Russian. 


\section{Литература}

1. Конвенция о запрещении разработки, производства, накопления и применения химического оружия и о его уничтожении. Международная конференция по подписанию Конвенции GE.92-61926. Париж, 1993; 133 с.

2. Постановление Правительства Российской Федерации от 21 марта 1996 г. № 305 «Об утверждении федеральной целевой программы «Уничтожение запасов химического оружия в Российской Федерации". Собрание законодательства Российской Федерации. 1996; 14: 1448.

3. Федеральный закон от 2 мая 1997 г. № 76-ФЗ «Об уничтожении химического оружия». Собрание законодательства Российской Федерации. 2006; 52: 5498.

4. Гуляев Д. В., КомбароваМ. Ю., Радилов А. С., Рембовский В. Р.,
СавельеваЕ. И., КорягинаН. Л., и др. Обеспечение санитарноэпидемиологической безопасности инфраструктуры объекта по уничтожению химического оружия «Почеп», планируемого К вовлечению в хозяйственный оборот. Медицина экстремальных ситуаций. 2019; 21 (4): 556-62.

5. Шмурак В. И., Кессених Е. Д., Шачнева М. Д., Густылева Л. К. Алюшина Т. И., Корягина Н. Л., и др. Определение продуктов деструкции фосфорорганических соединений методом ВЭЖЖХ-МС/МС. В сборнике: А. С. Радилов, В. Р. Рембовский, редакторы. Медико-биологические аспекты химической безопасности: сборник трудов III Всероссийской научной конференции молодых ученых. СПб., 2018; c. $51-52$. 